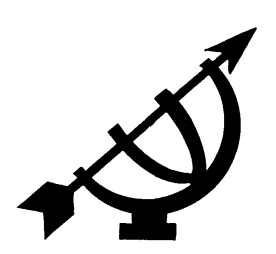

\title{
The radicalisation of a Swedish ecclesiastical critic of apartheid - Gunnar Helander
}

\author{
Frederick Hale \\ School of Ecclesiastical Sciences \\ Potchefstroom Campus \\ North-West University \\ POTCHEFSTROOM \\ also: Beijing International Studies \\ University Beijing \\ E-mail: fh243@cam.ac.uk
}

\section{Abstract \\ The radicalisation of a Swedish ecclesiastical critic of apartheid - Gunnar Helander}

From the 1950s through the 1980s, both the government of Sweden and various non-governmental agencies in that country stood at the forefront of the international campaign against apartheid. To a considerable extent, representatives of the Church of Sweden Mission were involved in this struggle. Among them was Gunnar Helander (1915-2006), a missionary in Natal and on the Witwatersrand from 1938 until 1956. After he returned permanently to Sweden, his role escalated and became known internationally, especially due to his prominence in the leadership of the International Defence and Aid Fund. Between 1949 and 1986 Helander wrote seven novels set in South Africa. In these works one can trace the unfolding of his position on apartheid, which evolved from mild criticism of race relations in South Africa to advocacy of international subversion of the P.W. Botha regime.

\section{Opsomming}

Die radikalisering van 'n Sweedse kerklike kritikus van apartheid - Gunnar Helander

Vanaf die vyftiger- tot die tagtigerjare van die vorige eeu het die Sweedse regering, asook talle nie-regeringsorganisasies in hierdie land, aan die voorpunt gestaan van die internasionale 
stryd teen apartheid. Verskillende verteenwoordigers van die Church of Sweden Mission was in 'n groot mate aktief in hierdie stryd betrokke. Onder hulle was Gunnar Helander (1915-2006) wat as 'n sendeling tussen 1938 en 1956 in Natal en aan die Witwatersrand gewerk het. Na sy permanente terugkeer na Swede in 1956 het die rol wat hy gespeel het egter vergroot en hy het ook internasionaal bekend geword, veral vanweë sy betrokkenheid in die leierskap van die International Defence and Aid Fund. Tussen 1949 en 1986 het Helander ook sewe romans geskryf wat in Suid-Afrika afspeel. In hierdie werke kan 'n mens die ontwikkeling van sy denke oor apartheid volg, wat gegroei het van aanvanklike matige kritiek op rasseverhoudings in Suid-Afrika tot die bepleiting vir internasionale omverwerping van die P.W. Botha-regering.

\section{Introduction}

Although the National Party's accession to power in South Africa in May 1948 was viewed with scepticism in many other countries - and the implementation of its apartheid policies during the next several years drew severe international rebukes - the intensity of criticism varied immensely from one country to the next. In few countries was it sharper and more sustained or more consequential than in Sweden. Swedish criticism of social engineering along racial lines in South Africa came from many quarters, not the least of which was the Church of Sweden Mission (CSM) that had begun its work in the region during the 1870s. Nevertheless, not all of its personnel in South Africa staunchly opposed apartheid. Several began to do so at a very early stage of Nationalist rule, however, and during the 1950s none emerged as a more vociferous foe of apartheid than Gunnar Helander. Although within the context of Swedish politics he was relatively conservative, he gradually became a leading voice in the struggle against apartheid, not only in Sweden but internationally as well. He played this role particularly through his prominent position in the International Defence and Aid Fund that for decades provided legal and financial support for men and women who were prosecuted because of their involvement in "The Struggle". Helander's weapon of choice was his pen - both while serving as a Lutheran missionary in South Africa and after his return to Sweden in the mid-1950s. He wrote extensively in both fictional and nonfictional genres to challenge what he rejected in the legal mistreatment of non-white ethnic groups.

Upon his death in 2006, Helander was eulogised as 
... one of the most colourful and influential figures in Swedish missionary service during the twentieth century, a pioneer who dared to challenge the standing political order in South Africa (Larsson, 2006:39).

Per Larsson, then a Swedish Lutheran missionary, asserted that between 1938 and 1956 Helander was a well-known author and part of a broad network of opponents of racial separation in that country. After he returned to Sweden Helander "effected the participation of the entire Swedish population against the racist regime" (Larsson, 2006:39). This undifferentiated representation of Helander as an unrestrained opponent of apartheid echoed Helander's own statements when he was interviewed by Tor Sellström as part of the "Nordic documentation on the liberation struggle in Southern Africa" project, which the Nordic Africa Institute in Uppsala, Sweden, conducted between 2003 and 2009. The retired Swedish cleric presented his staunch hostility to racial segregation as dating from his earliest years in South Africa. 1

My extensive research on Helander (which began in 1989) suggests that this is inaccurate and masks important developments in the unfolding of his political and social thought. In this article I shall trace the evolution of Helander's position - vis-à-vis apartheid and race relations generally - by examining his treatment of the topic in his seven novels set in South Africa. It will be clear that during the 1940s, in other words before the 1948 Nationalist takeover, he was at best a moderately liberal critic of troubled relations between the races in Natal. It will be argued that prior to his return to Sweden in 1956, Helander was not a particularly outspoken critic of the National Party and its comprehensive programme of social engineering. However, back in his native country - where public sentiment had been considerably hostile towards apartheid for several years - he underwent a remarkable transformation and soon emerged as an increasingly radical critic. By the end of the decade he envisaged a revolution in South Africa and eventually advocated international subversion of the apartheid regime.

\section{Helander's background and missionary career}

As I have demonstrated elsewhere (Hale, 1996c), the CSM had established a rich tradition of expressing concern about social ethical

1 See especially the interview by Sellström, www.liberationafrica.se/intervstories/ interviews/helander. 
issues (including oppressive race relations) in the (former) Union of South Africa, decades before Helander arrived in Natal. This can be traced back to the early years of the twentieth century after it extended its field from Natal to the Witwatersrand in 1902 directly after the conclusion of the Second Anglo-Boer War. After the National Party returned to power in 1948, the CSM frequently criticised its apartheid policies (Hale, 2001) and adapted aspects of its urban strategy to cope with the realities of this new socio-political dispensation (Hale, 2008). It is virtually inconceivable that Helander was unaware of at least some aspects of South Africa's socio-political reality during his first decade as a missionary, as many of his CSM colleagues had considerable experience in that country.

Nothing in Helander's early life in Sweden signalled his international prominence as a foe of apartheid decades later. Born in 1915 in Vänersborg, a small city in west-central Sweden, this son of a pastor in the state Lutheran Church performed well but not outstandingly at school and following two years at Göteborg College he in 1935 undertook theological studies at the University of Lund (CSM, 1937). He graduated with slight distinction in 1938 and was immediately commissioned by the Church of Sweden Mission (CSM) for service in the Union of South Africa. The CSM had been active in Natal since the latter half of the 1870s when its first missionary to that field, Otto Witt, launched a station called Oscarsberg near Rorke's Drift, just south of the historic Zulu kingdom. The station to which Helander was sent, Emtulwa, approximately 25 kilometres southwest of Greytown, however, offered a dilapidated, vermin-infested house without plumbing or other amenities. He would remain there and at a second station in Natal until 1950, when the CSM sent him to Johannesburg to minister to both Scandinavians and Zulus, and particularly to administer its educational programme for Africans on the Witwatersrand.

By his own testimony (which cannot be corroborated with external evidence), Helander began to write and send to Swedish newspapers critical articles about conditions in South Africa during his early years at Emtulwa. However, these initial efforts proved frustrating because editors in his homeland refused to publish them. Decades later, Helander insisted that the reason for the rejections was that they did not find his descriptions of racial oppression in rural Natal plausible (Helander, 1990).

What is known about Helander's early endeavours before he became a novelist is that he quite frequently commented about Zulu spirituality, moral standards, and folkways in letters and articles 
which he contributed to the periodical of the CSM, Svenska Kyrkans Missionstidning. "The Zulus are not bothered in the slightest by theoretical difficulties", he generalised in one revealing epistle written in 1942. "The miracles of the Bible are a simple matter for them." (Helander, 1942:189-190.) On the other hand, Helander thought that "it is the high moral demands of the New Testament, especially the Sermon on the Mount, that hinders them". Rather than ethical strictures of the gospels, the Zulus ostensibly tended to favour the Old Testament, with which they could supposedly identify because of their "propensity for murder and polygamy" (Helander, 1942:189190).

There is no reason to believe that during his first decade or so in South Africa Helander deviated significantly from prevailing Eurocentric attitudes regarding race relations and attendant matters, and there is no evidence that he challenged existing segregationist legislation during those early years. Shortly before he returned to Sweden in 1948 on furlough with his German-South African wife (whom he had met while working at Emtulwa) and their first two children, public curiosity about racial politics in South Africa had been piqued by the recent victory of the National Party. When asked what the solution to that country's race problem was, Helander replied that he could have given an incisive answer nine years earlier. However, "The longer one ponders the problem, the more difficult it appears to be." Moreover, this future revolutionary suggested that it was at least worth asking whether it was necessarily a consequence of the Christian faith "to demand equal rights for everyone, whether black or white, civilised or uncivilised, without regard to the consequences" (Helander, 1948:189-190). Helander thought that granting suffrage to indigenes who could pass an examination was an option worth considering but did not commit himself to it. At the same time, he questioned the wisdom of expropriating white-owned farms in the interest of creating more equitable land tenure, because to him it seemed questionable whether black South Africans could responsibly manage the nation's food production (Helander, 1948).

\section{Awareness of injustice before apartheid}

During that initial furlough, Helander wrote much of his first published novel, Zulu möter vit man (1949) (Zulu meets White man), which was published in Stockholm the following year but never published in an English edition. As literary art, this foray into the field of imaginative literature is entirely undistinguished. Arguably the 
most religious of Helander's seven novels set in South Africa, it deals primarily with such missiological issues as discipline in rural Zulu parishes and the possible indigenisation of the gospel to facilitate its communication in different cultures. In brief, Zulu möter vit man traces a teenaged convert, Simon Ndlovu, who toils on the farm of the verkrampte (bigoted) Piet van der Merwe. His family's presence as squatters there ends abruptly after Simon intervenes to stop the undeserved whipping of another Zulu youth. Instead of continuing as an agricultural labourer, Simon is recruited by a Swedish missionary, Fredrik Örn (who repeatedly appears in Helander's fiction as a spokesman for his views), to be trained as a lay evangelist. Repeating a familiar theme in South African literary history, which more recently had been at the core of Alan Paton's Cry, the beloved country (1948), Simon briefly goes to Johannesburg in search of a lost relative. After that digression, he completes a three-year course at a German mission station, where he and other aspiring evangelists are trained by the paternalistic Fritz Grumpke. During his studies, Simon leads a student strike against this elderly man's condescending attitudes, authoritarian pedagogy, and criticism of Zulu culture - foreshadowing his subsequent rebellion against raciallymotivated social policies.

As an evangelist at Örn's station, Simon yields to sexual temptation with a young girl, Busisiwe. He confesses his sin to Örn, who grants him a leave of absence to consider his suitability for Christian ministry. The troubled youth learns that Busisiwe is pregnant; the parish council suspends him for a year. When Simon travels on a crowded bus to Durban in search of secular employment to pay lobola of eleven cows to Busisiwe's father, he experiences a tonguelashing from an irate conductor because he has unwittingly taken one of the seats reserved for white passengers. Simon then overhears a heated debate between a radical Zulu, who is intent on overthrowing white rule in South Africa, and a Zulu policeman, who calls Marxist blacks internal enemies and warns that the boers are waiting for an opportunity to crush the last vestiges of black resistance to their hegemony. Simon's sympathies lie with the radical debater, and when an elderly Zulu pastor on the same bus suggests that the answer to racial subjugation lies in cooperation with the various factions, he wonders whether that can really be achieved. However, this theme is not really developed in Zulu möter vit man.

Helander had no sympathy for communism during the era of Joseph Stalin, and accordingly, in his first novel the reaction of the radical left to racial oppression in South Africa is rejected. Simon inad- 
vertently attends a communist rally in Durban where the speaker, an Islamic Indian, offers little apart from inflammatory rhetoric. Another Zulu with whom Simon converses undermines the credibility of this orator by telling the newly-arrived young man that the speaker is actually a capitalist, who is merely seeking to curry favour with the Zulu population by disingenuously criticising the exploitative economic conditions which work to their disadvantage.

Furthermore, Simon hears from one of his ethnic brethren that guilt for racial oppression is not solely on the shoulders of white South Africans. Not long after arriving in Durban he begins to assist a Zulu evangelist, Isak Dladla, who serves the Norwegian Missionary Society in a slumyard ministry. This more seasoned counterpart, whose endeavours remind Simon of what he himself had undertaken in rural Natal, emphasises to him that "if one proclaims racial hatred in sermons, as the African sects do, one does irreparable harm". Unconvinced, Simon asks him whether the whites bear the heaviest guilt for the country's social injustices. Dladla gives him an ambiguous "perhaps" but immediately adds, in a highly revealing passage, which indicates the stage of Helander's thinking in the 1940 s, that "it is not my task or yours to deal with that. The whites' own clergymen should worry about that. We are to teach the Zulus to see their own shortcomings." (Helander, 1949:156-160.)

The seeds of Helander's later radicalisation may have already been planted when he wrote this novel, but they had hardly begun to germinate. One certainly finds an initial awareness of racial injustice. The author's spokesman, Fredrik Örn, protests to the white farmers near his station about evictions of landless Zulu peasants from their properties, but makes very little progress with his pleas for more humane treatment. At a meeting of CSM personnel in Natal, there is a consensus that white farmers have been inimical to their work they had occasionally compelled missionaries to move or close chapels and other institutions. Moreover, the Swedish missionaries agree that their congregations suffer greatly because of inequitable land tenure legislation, including the Native Lands Act of 1913. Eventually Örn manages to ameliorate the dire situation, though only temporarily, by convincing the leadership of the mission in Sweden to purchase more land in Natal. A small proportion of the affected Zulus can thus have a secure place to live. Yet the underlying legal problem continues.

However, there is scant evidence that in the late 1940s Helander believed that Christianity as such - as distinguished from the activities of foreign missionaries - had a legitimate prophetic voice in 
the social and political turbulence of South Africa. Instead, there are signs of what would become an inconsistency running through his first few novels. On the one hand, he castigated the Zionist churches that had plagued his ministry at Emtulwa. In Zulu möter vit man, this involves inter alia a rejection of the racial exclusivity inherent in these independent, indigenous denominations. On the other hand, Helander had little to say at this early stage about the European religious and cultural domination against which the Zionists reacted. To be sure, one finds the germ of his eventually strong case for social and political justice in South Africa, but it bears the stamp of his own entrapment in his European cultural background and his moderate liberalism - both of which stressed the centrality of improving race relations on the individual level, as opposed to wholesale social reform. This commitment to what David Bosch would criticise as "cheap reconciliation" (Nürnberger \& Tooke, 1988:100) runs like a scarlet thread through Helander's early novels.

\section{Assessing discrimination against Indians in Natal}

Helander's move to Johannesburg following his furlough in Sweden did not end his interest in improving race relations in Natal. His first novel of the 1950s dealt with a topic that had received much less European consideration than the plight of indigenous Africans before and after 1948, namely that afforded the country's Asian population. Endast för vita (1951) (For whites only) is an exploration of how both racial legislation and racist attitudes precipitate the emotional destruction of an Islamic Indian in Natal, Ahmed Mullah. He finds himself in an insoluble dilemma after marrying a Swiss woman, Anne Güntl, whom he has met while studying law in Birmingham in the late 1930s and bringing her back to his native land. Interwoven with this is a sub-plot in which Helander examines South African racism through the experiences of a Swedish immigrant, Erik Forss, who begins as an idealistic liberal but falls victim to both Zulu violence and the cultural captivity of white privilege. In the end he regains some of his ethical principles through the influence of Fredrik Örn, who again appears as Helander's spokesman.

Mullah meets Forss when both are studying in Birmingham (the latter to prepare for a business career in South Africa), and Helander uses a conversation between the two as a didactic intrusion to summarise the plight of Indians in Natal. Mullah explains that his paternal grandfather had emigrated from Bombay to Natal and that he himself regarded the Union of South Africa as his native land. He complains that he and the other 300000 Indians in the country 
enjoyed neither suffrage nor the right to hold most positions in the government, that they were restricted in terms of land tenure, and that they could not travel about freely (Helander, 1951:12). Yet most of this novel does not deal explicitly with these legal obstacles, nor does it propose solutions to them. To a much greater extent Helander's concern is with the development of respectful and harmonious relations on the level of the individual and the small group.

Indeed, Endast för vita deals with a cluster of interrelated themes about problematised ethnic and cultural relations in the Union of South Africa, not all of which stem from racially defined legislation or racial prejudices. The marriage between Mullah and Güntl seems rushed and doomed virtually from the outset. The groom's father is opposed to the union, and at no time does this Islamic family in Ladysmith really welcome their European addition, although the senior man helps the young couple purchase a house in Pietermaritzburg. As an early sign of the cultural incompatibility of the bride and groom, Mullah is said to appreciate van Gogh and Cezanne but has no time for "the banal Swiss oil with the Alps", which his wife has brought along. Instead, their new home is appointed with Indian carpets, vases, and pieces of furniture, but Mullah does not evince any attachment to these, either, suggesting that he is at least partially alienated from his own cultural background. Further encumbering their marriage is that they apparently have not discussed such crucial matters as their religious compatibility and whether they should have children. In May 1939 Mullah suggests that they try to have a child soon. Anne has no enthusiasm for this and explains that in the short term it is more important for her to find peace of mind in her new surroundings. "It takes time to adapt out here," she declares with no mean understatement (Helander, 1951:59). At any rate, her husband assumes that any children will be raised in his faith and attend Islamic schools. Anne resists this, having noticed that in Natal, Christians and Muslims treat their women and girls differently. The problem remains unresolved. The marriage continues to deteriorate along with Mullah's mental health, until he commits suicide by driving his car off a cliff with his unsuspecting wife by his side. In this crucial dimension of Endast för vita, Helander seems to be more concerned about pastoral matters related to marriage than social justice.

Before returning to Sweden permanently in 1956, Helander devoted a great deal of literary energy to the phenomenon of racial stereotyping and its dilatory effects on both missionary endeavours and society generally in South Africa. This is a dominant theme in En- 
dast för vita and, as will be seen shortly, it would re-emerge in his novel of 1955, Storstadsneger (1955b) (Big city Zulu). No ethnic group mentioned at length in Endast för vita emerges unscathed. All either embody racist attitudes or other characteristics which contribute to tensions in a multicultural society. After Erik Forss arrives in South Africa, he finds quarters in Brakpan, where he is severely assaulted by a gang of black men who leave him for dead. His English-speaking landlord has lent him a handgun and assured him that if necessary he could shoot a black man with impunity, but this proves entirely ineffective as a means of protection in a violenceridden social environment. While convalescing, the mutilated young Swede tells a white nurse that South African blacks are essentially savages and too immature to assume political responsibility. He also asserts in an argument with her that in Natal (which he has not yet visited) the Indians are "filthy and fanatical" (Helander, 1951:79). After Forss is discharged, he travels to Durban to stay with the parents and brother of Mary Cliffe, whom he has met on his voyage from England. Their attitudes towards blacks are no less hostile than hers. While with Mary in the centre of Durban, Forss notices his old friend Mullah but, fearing that his friendship with him might jeopardise his budding relationship with this white woman in whom he has a romantic interest, avoids him.

In accordance with his emphasis on individual perceptions of other ethnic groups and nurturing more cordial relations between them on the individual level - before he would turn to direct opposition to apartheid - Helander stressed the central New Testament concept of agápe in Endast för vita. Indeed, the Greek word koine is the title of the tenth chapter. Therein the emphasis is on Christians' attitudes towards people of other races. In a conversation with Örn, Forss admits that he still believes there is "something crude and repulsive about the blacks" and asks the missionary whether he shares that perception. Örn replies that his own view of the Zulus is mixed and acknowledges that the longer he works among them the more he finds them "quite repulsive". When Forss then asks why he continues to toil in South Africa and suggests that such self-giving love exists only in theory, Örn tells his young guest that God has and is such love; this awareness compels him to minister to people to whom he is not personally attracted. Furthermore, he adds in a statement, which could have been developed along lines of immediate relevance to the political situation in South Africa, "all people shall have mercy and justice and the like, regardless of how they are" (Helander, 1951:131-133). However, this discussion is truncated. Entirely absent from it is any specificity pertaining to the issues 
confronting the South African society in the early 1950s, especially resistance to the implementation of apartheid, despite the fact that Forss has asked Örn about these matters.

\section{Social justice on the Witwatersrand?}

Helander wrote his next novel, Svart symfoni (1952), shortly after moving to Johannesburg, but it dealt chiefly with rural Natal and was published in Stockholm in 1952. An English translation was issued under the title Black rhapsody by the reputable American firm Harper (subsequently Harper \& Row) in 1956. The book need not be treated in detail here, as it did not represent a significant development in Helander's political maturation or the unfolding of his social ethics with regard to South Africa. Rather, the principal theme is miscegenation, which at that time Helander clearly opposed. Svart symfoni traces inter alia the downward spiral of a young man sired by an inebriated Swedish seaman and a Zulu woman. Helander also used this volume to confirm the images created in his earlier fiction of racist Afrikaners and rural Germans, as well as hypocritical, pseudo-liberal English-speaking South Africans. Indicative of the new urban dimension in his own ministry, he briefly introduced readers to the squalor of townships near Johannesburg.

This setting became the central venue of Helander's next novel, Storstadsneger, which appeared in Sweden in 1955 and in English in the USA two years later under the title Big city Zulu. In this, his final book before his permanent return to his homeland, Helander underscored the mutual exclusiveness of the two worlds on the Witwatersrand in which white and black South Africans lived. At the outset of the novel he highlighted the social ramifications of the new political dispensation in the late 1940s:

From the capital city, Pretoria, there came a stream of determined decrees and racial laws ... South Africa must be kept under the white man's dominion, and the boundary line between the races must be clear cut.

Helander underscored the threatened status of the white and largely Afrikaner working class as providing the impetus for apartheid at a time when a minority of urbanised blacks had rising social mobility:

These white people of the poorer class at the border line between black and white saw the danger more clearly than the others, and they supported devotedly the policy of the government. (Helander, 1957:3.) 
Much of the plot unfolds in a fictitious township called "Stoneville". Helander (1990) confirmed that this was inspired by Jabavu-Moroka. There the Church of Sweden Mission operates one of its numerous schools for black children and the Swede in charge is Fredrik Örn. Tribulations abound in this dimension of the multifaceted Swedish Lutheran ministry. The children live in a dead-end squalor, and many who attend the school prove to be thorns in the flesh of its prefects and others in positions of responsibility, not least because of their nocturnal escapades that are described in captivating detail, including encounters with knife-wielding tsotsis.

Helander also used Big city Zulu to illustrate difficulties caused by petty apartheid and the mentality of whites who administer it. Particularly graphic is an incident caused by an encounter between one of the schoolboys, Philemon Zondi, and an incompetent train conductor who accuses him of travelling without a ticket. This leads to the arrest of the Zulu youth, who is found guilty on the testimony of two conductors who perjure themselves and is sentenced to eight cuts with a cane. Örn's efforts to have the punishment mitigated because of Zondi's age come to naught in the inflexible judicial system. The execution of the sentence is graphically described, as is the part of a German-Jewish immigrant physician who is employed by the police to examine prisoners who are subjected to corporal punishment. He detests the system as barbarian and reminiscent of the injustices of the Third Reich and signs a form reducing the sentence from eight to six cuts.

Late in Big city Zulu there is a prolepsis which carries the story forward to the early 1950s. Zondi has chosen not to become a minister of the gospel but becomes involved in the Democratic Peace Congress, a fictitious Marxist organisation, which is one of several that sprang up after the banning of the Communist Party. It seeks social reform in South Africa but, in contrast to Örn and other missionaries who strive for reconciliation between the races, the Democratic Peace Congress attempts to sow discord between white and black South Africans. Eventually Zondi accepts a position as a teacher at a CSM station on the Witwatersrand. He serves competently but continues to ask questions indicating that the Democratic Peace Congress has left an indelible stamp on him. Zondi wonders, for example, why Örn accepts money from a source in the United States of America and whether Jesus actually existed. It is on this note of uncertainty about the role of missions and black Christians in the struggle against apartheid that Big city Zulu ends. 


\section{From paternalism to power-sharing?}

Helander wrote one more book before leaving South Africa in 1956. The previous year the Church of Sweden issued his collection of essays, Skisser vid vulkanen (1955a) (Sketches by the volcano). These dozen brief treatises are particularly useful for understanding the evolution of his thought concerning race relations in South Africa. It indicates that by the mid-1950s, after a quinquennium on the Witwatersrand, this seasoned missionary was beginning to appreciate that the era of unchallenged white hegemony would end, but that paternalistic attitudes of white determination still influenced him.

Helander did not offer a panacea for the ills confronting South African society but expressed his allegiance to the liberal position which Alan Paton and others were espousing, and he quoted the titled of Cry, the beloved country in this regard. What the role of the mission church should be is not fully clear in Skisser vid vulkanan, but he argued that one of its tasks in ministering to Christians, regardless of their ethnicity, was to heal rifts and "do our utmost to open their eyes and show them the way of love and reconciliation". Helander lamented that to a great degree "the spiritual message of the black church has been pressed into the background, and into the foreground has come striving for land, suffrage, and freedom of movement". He assured readers in Sweden that in many quarters "missionaries are struggling hard to prevent the black church from being transformed into a political reform movement, a forum for bitter and irreconcilable partisan conflict". He also averred that most African Christians did not abuse their faith for political purposes, or regard Christianity as an instrument of white oppression in South Africa (Helander, 1955a: 9-10, 43-44).

That Helander did not preach racial equality in the mid-1950s is evident from several of these essays, perhaps nowhere more vividly than in a specific condensed collation of conversations he had had with various Afrikaners. In one exchange, he had replied negatively when asked whether he favoured immediately granting suffrage to all blacks in South Africa. "No, not all, I believe," was his response. "I would only want to give the vote to them who have passed an examination and attained a certain standard." (Helander, 1955a.) What this would be, however, is not recorded. Moreover, reflecting an equally paternalistic attitude, Helander had voiced his opinion that only those blacks who had proved that they exercised satisfactory stewardship of land while under white supervision should be allowed to buy farms. However, he had urged Afrikaners to consider some 
sort of power-sharing arrangement to avoid a downward spiral that could end in "revolution and chaos". To allow blacks to prepare themselves for beneficial participation in joint governance, the government should scrap job reservation legislation and terminate residential segregation, to give black South Africans an opportunity to learn how to live like Europeans (Helander, 1955a:64, 67-69).

Back in Sweden, though, Helander soon underwent a remarkable metanoia. Conceivably, he was influenced by the already strong climate of anti-apartheid sentiment there. Yet, in essays published in the Swedish press, Helander revealed other factors which apparently accelerated his tempo along a road of vocal criticism of the South African government. In May 1957 he wrote that racial oppression had gone from bad to worse. Penalties for infractions of petty apartheid had been stiffened, and he also cited the arrest of both black and white champions of racial equality as supposed traitors. The brief imprisonment of Alan Paton that month also disturbed Helander (Helander, 1957b:3). He pointed to the ascendancy of Afrikaner political power and the concomitant eclipse of Anglophone liberalism in South Africa as ominous signs, but he also reasoned that the rising economic status of black South Africans threatened many whites and suggested that apartheid could be understood as inter alia a reaction thereto (Helander, 1957d:3). Before the end of 1957, Helander announced in another essay that he would not return to the mission field. The increasingly hostile Swede declared that the gradual intensification of racial laws in South Africa was reminiscent of legislation in the Third Reich during the 1930s (Helander, 1957d:3). The following year, Helander called H.F. Verwoerd (the principal theoretician of apartheid who had just succeeded J.G. Strijdom as prime minister), the new Führer and reminded readers that this Nationalist politician had been responsible for the nationalisation of most mission schools in South Africa (Helander, 1958:3).

\section{From paternalism to cultural parity?}

Helander's first novel after his return to Sweden in 1956 marked a new departure in both his cultural outlook and his attitude towards apartheid. Det nya kom från negern (The new element came from the African) was published in Stockholm in 1959. No English edition was ever issued, although one major theme discussed therein formed the subject of his Must we introduce monogamy?, which was issued in Pietermaritzburg in 1958. Though set in rural Natal, it was, up to that point, Helander's most radical work, going politically well beyond what he had written in Big city Zulu. One notices this inter 
alia in the portrayal of some, though certainly not all, of the Zulu characters. Entirely absent is the unconscious aping of the white man, which is so conspicuous in Black rhapsody. Also gone are criticisms of aspects of indigenous culture and the unquestioned missionary prerogative that figures prominently in Helander's early novels. These underlying assumptions have been replaced by a generally respectful attitude towards Zulu folkways and a revolutionary vision of the future in which white hegemony meets its end.

Det nya kom från negern is thematically a two-part work and each half relates only indirectly to the other. The first half is a presentation of Helander's case for allowing polygamy among members of African churches. As such, it is a fictional embodiment of the argument he made in a thesis at the University of Uppsala, of which an English version was published in Pietermaritzburg in 1959 as Must we introduce monogamy? This had been, and would continue to be, a vexing problem in foreign missionary endeavours of various denominations, especially in Africa. By the late 1950s Helander had shed whatever qualms he previously had about plural marriage and was prepared to tolerate polygamy in cultures where it was accepted practice. He argued that, although it fell short of the New Testament model for marriage, it was worse to either exclude polygamists from church membership or to insist that a convert divorce all but his first wife before being baptised. The present writer has discussed in detail Helander's argument elsewhere, and it need not be repeated here (Hale, 2006b).

The change of perspective is also seen in the central missionary character, Halvdan Knutson, after overhearing a lengthy conversation between his colleague Jonathan Mtiyane and another Zulu person, during which they discuss frankly what they perceive as this European's attitudes towards the Zulus. In the wake of this, Knutson realises that

... an epoch was over, the great missionary epoch with its magnificent results when over half of the Zulus became Christians, when churches and schools and hospitals were built everywhere, when the missionary was a father and an authority who led his black children and protected them from the merciless white colonists.

His awareness of the end of such ecclesiastical paternalism has its counterpart in South African society generally. Knutson understands that 
... the black man was sure of one thing - he would no longer obey the white man merely because the white man was white. The time of the white man's prerogative was over, regardless of whether he was an oppressor or a benefactor. (Helander, 1959:98.)

The final seven chapters of Det nya kom från negern incorporate Helander's vision of the future of South Africa during an era of rapid decolonisation and black ascendancy across much of the African continent. Helander placed his apocalypse a decade in the future, in other words, in the late 1960s. The CSM has apparently withdrawn from its Zulu field, but Knutson has remained at his station to minister to his flock. Political and social chaos reigns in South Africa as rebellious blacks challenge the government's authority. Afrikaners desperately attempt to cling to power, but their fate seems inevitable: "The ring was being tightened as hard as iron around the land of the Boers, and within the ring the black subjects waited for the day of revenge." (Helander, 1959:104.) Blacks declare a republic; white counter-insurgency soldiers ("the SS of the National Party") overrun the mission station and offer to take Knutson to a safe haven near Pietermaritzburg. A white officer urges him to leave South Africa, since "missionary ideas" do not fit well in the country, and missionaries must be regarded as "traitors to the race". To this Afrikaner, there is a cause-and-effect relationship between liberationist views and the collapse of the established order of white supremacy. "Now you see the results of your propaganda for equality", he declares triumphantly (Helander, 1959:122-123).

That a disparate coalition of black forces will emerge victorious is underscored. Helander describes the envisaged march of a column of black revolutionaries. They include battle-hardened soldiers armed with firearms and others bearing traditional African weapons.

Less eager to engage the enemy are downtrodden labourers. Bringing up the rear of the contingency, and apparently less significant in Helander's vision, are the religious. They include Zionists, led by a "homemade bishop" clad in ornate vestments.

Behind him marched a singing and gesticulating group of sectarian bishops, metropolitans, popes, and prophets wearing imaginative garb in every colour of the rainbow, most of its sewn from curtain fabric, and imitation bishops' mitres of cardboard or leather. (Helander, 1959:140-141.)

The rearguard comprises abasizikazi, or uniformed church women's groups who emit "hysterical screams" and "shake their hands in the 
air" (Helander, 1959:142). Yet, this motley assembly emerges victorious.

The role of the missionary church in post-revolutionary South Africa will be largely one of nurturing interracial reconciliation, not encouraging the transformation of traditional culture. Some of the Zulus are vengeful, but Mtiyane, now in charge of the station, calls for brotherhood and forgiveness, while admitting that it is saddening to defend the "oppressors". Other Zulu clergymen and the abasizikazi among the rebels join him in this dimension of ministry. Their voices become dominant, and Mtiyane eventually succeeds in leading the throng in singing Nkosi sikelel' iAfrika. The Afrikaners have by no means disappeared from the scene. Some in the vicinity accuse Knutson of racial treason; others beseech God in loud prayer to crush the Zulus. Det nya kom från negern ends on a general note of uncertainty about the future, but it leaves no doubt that Helander, then three years removed from South Africa, believed the coming years would be turbulent and that white hegemony would draw to a close.

\section{Inspiring a children's crusade against apartheid}

After publishing Det nya kom från negern in 1959, Helander remained in Sweden but continued to participate in international campaigns against apartheid through a variety of channels, especially by playing a prominent role in the International Defence and Aid Fund. Only after a hiatus of approximately two decades did he again take up his novelist's pen and write Den vite mannens stövel (1980) (The White man's boot), which may be succinctly described as a revolutionary novella intended to awaken adolescent readers in Sweden about the injustice and frustrations of race relations in South Africa. The book was published only in Swedish.

Internal evidence suggests that the plot of this thriller begins around Christmas 1979. The Soweto riots of 1976 are mentioned as having taken place; Steve Biko has died in police custody; P.W. Botha has succeeded B.J. Vorster; and South African radio broadcasts news about ayatollahs in Iran, where Ayatollah Kohmeini's Islamic revolution had deposed the shah in 1979. A young Zulu teacher, Josef Masondo, whose parents live on land owned by a farmer named Vermaak, resists the abusive conduct of this Afrikaner towards his exploited employees. Determined to leave his teaching position in a township near Durban, he attempts to travel to Johannesburg by train, but loses his passport to two Zulu policemen who insist on a bribe. Masondo flees and soon encounters two Swedes, one a mis- 
sionary and the other a journalist, who take him in a car to Dundee. From here the journalist continues on with him to Johannesburg in the hope of getting an interesting story after learning that the police are in pursuit of this young teacher. Conversations between the two give Helander an opportunity to express a view that white rule in South Africa might end within five years. In the same exchanges, Masondo voices the case for a continued missionary presence in the politically and socially turbulent country. He assures the visiting Swede that missionaries had "fought for us in the courts" and that "the new religion [of Christianity] was pure dynamite for us, especially for the women" (Helander, 1980:73). Though briefly given sanctuary by a German Jewish immigrant named Katzenellenbogen in Johannesburg, Masondo is arrested and beaten in custody. After serving a three-year sentence, he emerges even more embittered against the Botha regime and is recruited as an agent of an antiapartheid organisation cryptically called the RLU, whose headquarters are in Edinburgh. Helander disclosed in an interview several years after the publication of Den vite mannens stövel that this was a pseudonym for the International Defence and Aid Fund (Helander, 1993).

Although Den vite mannens stövel was written in the first instance for adolescents, it is by no means a sanitised portrayal of life in South Africa. On the contrary, one finds graphic descriptions of such forms of torture of political prisoners as the explosion of a stomach by forcing air into the intestines through the rectum and the electrocution of testicles. Yet, not all of the violence stems from the imposition of apartheid and severe measures to quell the movement against it. There are also incidents of rape and the contemplated murder of a Zulu woman by her polygamous husband because she has become a burden to him. Undoubtedly, one of Helander's purposes in writing this book was to shock a younger generation of Swedish readers into taking a stand against apartheid.

Crucial to an understanding of Den vite mannens stövel in the history of missionary endeavours, is Helander's radically shifted opinion about what the role of the Caucasian has become. His spokesman, Örn, states bluntly that the only purpose missionaries have in the South Africa of the late 1970s is "to make amends for the evil that our white brethren have done to the blacks" (Helander, 1980:23). 


\section{Full-scale subversion through the International Defence and Aid Fund}

Helander would not return to South Africa until the early 1990s. By his own testimony, he felt frustrated about being able to contribute to the struggle against apartheid only from afar through his writing, public speaking, television appearances, and work in the International Defence and Aid Fund (Helander, 1990). His final novel, Uppdrag Zulu (Operation Zulu), was published in 1986 and can be interpreted as both the apogee of his radicalisation and the vicarious fulfilment of his yearning to participate directly in the resistance movement. It continues the revolutionary theme advanced in Den vite mannens stövel, but was written for adult readers in Sweden. No English translation has been published.

Uppdrag Zulu is a heroic and highly tendentious fantasy in which Helander created yet another quasi-autobiographical figure, who undertakes a subversive mission of the sort the author was prevented from doing. The protagonist, a relatively young former Swedish lay missionary, Martin Nygård, has spent several years in South Africa before being deported for engaging in ostensibly subversive activities. He returns clandestinely as an agent of a London-based organisation, whose loosely defined purpose is to lend international support to the domestic South African campaign against apartheid. Helander admitted privately seven years after Uppdrag Zulu was published that the fictitious body was based on the International Defence and Aid Fund (Helander, 1993).

En route to South Africa, Nygård becomes familiar with a verkrampte (bigoted) Afrikaner named Oosthuisen, who defends racial oppression and invites Nygård, who feigns sympathy, to stay at his house in Pretoria. Oosthuisen subsequently introduces the Swede to Jan Potgieter, head of the Bureau of State Security, BOSS, who believes he has recruited Nygård to serve as an agent whereby he will earn R10 000 monthly for his services after undergoing a rigorous training course. This dimension of the plot allows Helander to introduce readers to those elements in the international campaign against apartheid with which he was familiar, while Nygård's introduction to the workings of BOSS reveals aspects of police brutality. The Swede witnesses, for example the sadistic and unrelenting torturing of an Indian member of the African National Congress. Conversations with the BOSS chief didactically underscore the international context of the struggle in South Africa. Potgieter explains to Nygård that some of the churches there comprise a "fifth column", but that the Botha government has de facto allies in its counterparts 
in Washington, Paris, London, and Bonn, chiefly because their countries need South Africa as a "military base" against the Soviet Union and have major financial investments in South Africa (Helander, 1986:40-41).

Christian hostility to apartheid is highlighted in Uppdrag Zulu, and its treatment underscores how far Helander had progressed since the 1940 s and early 1950s. After arriving at a mission station in Natal, Nygård hears a pastor, Ndaba, preach. His sermon mirrors the evolution of Helander's political thought with regard to the rectifying of racial injustice. This Zulu clergyman implores his flock to struggle against discrimination. "Here one race stands against the other in hatred, but the Lord still demands that we love and forgive those who trample upon us," he proclaims. Ndaba is not committed to passive resistance.

But love does not only mean tolerating evil. It demands that we fight against that which is unjust. We are not simply going to bow our heads. We shall speak out and afford resistance in every way, even resisting force with force, if that is necessary.

They would "fight, hard and without wavering". At the same time, Ndaba reminds the congregation that "our oppressors are also our brothers" and that after liberation is attained they must "forgive and love those who were our enemies" (Helander, 1986:158-159). Though brief, this example of fictional homiletics lucidly illustrates how far Helander's position had shifted during the three decades since his departure from South Africa. It contrasts diametrically with a sermon by Pika Hlongwane in Big city Zulu. Hlongwane is a pious cleric on the Witwatersrand who had asked his hearers to accept much of the social status quo, refrain from hating their white oppressors, avoid committing adultery or patronising shebeens, and await their reward in the hereafter (Helander, 1957a:47-48).

\section{Conclusion}

Although Helander was born and had died in a small country many thousands of kilometres from South Africa, his interaction with this country was immense and took place in seven decades of the twentieth century. Larsson's eulogistic comments cited above may exaggerate the extent to which the Swedish population engaged with apartheid, still Helander's literary campaign for the application of what he believed were Christian social and spiritual precepts to woeful race relations in South Africa, was matched by few other 
writers of fiction in any language. He deserved a wider readership than he had.

That said, it must be added that Helander's statement that he had been radically opposed to racial segregation from the outset of his ministry in Natal must be taken cum grano salis. There is no reason to doubt that he became painfully conscious of mistreatment of Zulus soon after his arrival in 1938. However, as the present study amply demonstrates, his attitudes towards race relations and development as a campaigner for equality went through several stages. Only after he returned permanently to Sweden in 1956 and was no longer in a legally vulnerable position at the mercy of South African judiciary but in daily contact with Swedish public and journalistic hostility to apartheid, did his position reach its revolutionary highwater mark.

\section{List of references}

CHURCH OF SWEDEN MISSION. 1937. Archives, A 2:69, Bilagor till Svenska Kyrkans Missionsstyrelses Protokoll 1937, file no. 286, "Ansöken från Gunnar Helander”, Gunnar Helander, "Levnadsförteckning för Teol. Kand. Gunnar Helander", Lund, 5 Dec. 1937.

CSM

see CHURCH OF SWEDEN MISSION

HALE, F. 1994. Urban apartheid and racial stereotypes in Gunnar Helander's Storstadsneger. Scandinavian studies, 66(1):68-91

HALE, F. 1996a. Ethnic characterisation, missiological issues, and the evolution of social ethics in the South African novels of Gunnar Helander. Durban: University of Natal. (Ph.D. thesis.)

HALE, F. 1996b. In defence of polygamy: the case of Gunnar Helander. South African journal of cultural history, 20(2):201-219.

HALE, F. 1996c. The development of social ethical consciousness in the Swedish Lutheran Mission on the Witwatersrand. Studia historiae ecclesiasticae, 22(2):48-67.

HALE, F. 2001. The Church of Sweden Mission and apartheid: 1948-1960. Missionalia, 29(1):21-42.

HALE, F. 2008. Adapting to apartheid: the Church of Sweden Mission on the Witwatersrand in the 1950s. Journal of church and state, 50(3):451-474.

HELANDER, G. 1942. Correspondence in Emtulwa to unspecified recipient, 29 Dec. 1942. Svenska Kyrkans Missionstidning, 68(9):189-190, 3 May 1943.

HELANDER, G. 1948. Missionen som folkförsonare i Sydafrika". Den evangeliska missionen, 50(8-9):113-118.

HELANDER, G. 1949. Zulu möter vit man. Stockholm: Svenska Kyrkans Diakonistyrelses Bokförlag.

HELANDER, G. 1951. Endast för vita. Stockholm: Svenska Kyrkans Diakonistyrelses Bokförlag.

HELANDER, G. 1952. Svart symfoni. Stockholm: Svenska Kyrkans Diakonistyrelses Bokförlag. 
HELANDER, G. 1955a. Skisser vid vulkanen. Stockholm: Stockholm: Svenska Kyrkans Diakonistyrelses Bokförlag.

HELANDER, G. 1955b. Storstadsneger. Stockholm: Svenska Kyrkans Diakonistyrelses Bokförlag.

HELANDER, G. 1956. Black rhapsody. New York: Harper.

HELANDER, G. 1957a. Big city Zulu. Rock Island: Augustana Press.

HELANDER, G. 1957b. Författare i fängelse. Göteborgs Handels- och SjöfartsTidning: 3, 27 Sept.

HELANDER, G. 1957c. Rasförföljelsen allt värre i Sydafrika. Göteborgs Handels- och Sjöfarts-Tidning, 3, 23 Dec.

HELANDER, G. 1957d. Rasförtryckets bakgrund. Göteborgs Handels- och Sjöfarts-Tidning: 3, 31 May.

HELANDER, G. 1958. Must we introduce monogamy? Pietermaritzburg: Shuter \& Shooter.

HELANDER, G. 1959. Det nya kom från negern. Stockholm: Svenska Kyrkans Diakonistyrelses Bokförlag.

HELANDER, G. 1980. Den vite mannens stövel. Stockholm: Rabén \& Sjögren.

HELANDER, G. 1986. Uppdrag Zulu. Örebro: Libris.

HELANDER, G. 1990. Interview with Gunnar Helander, Uppsala, 29 Nov. 1990.

HELANDER, G. 1993. Gunnar Helander correspondence to Frederick Hale, Uddevalla, 28 Jul. 1993. (Frederick Hale private archives.)

LARSSON, P. 2006. Gunnar Helander. Svenska Dagbladet: 39, 2 Apr.

NÜRNBERGER, K. \& TOOKE, J., eds. 1988. The cost of reconciliation in South Africa. Cape Town: Methodist Publishing House.

\section{Key concepts:}

\section{apartheid}

Church of Sweden Mission

Helander, Gunnar

International Defence and Aid Fund

racial stereotypes

\section{Kernbegrippe:}

apartheid

Church of Sweden Sendinggenootskap

Helander, Gunnar

International Defence and Aid Fund

rassestereotipes 